OPEN ACCESS

UWS Academic Portal

\title{
Using mobile learning and social media to enhance learner feedback
}

Bikanga Ada, Mireilla ; Stansfield, Mark; Baxter, Gavin

Published in:

Journal of Applied Research in Higher Education

DOI:

10.1108/JARHE-07-2015-0060

Published: 06/02/2017

Document Version

Peer reviewed version

Link to publication on the UWS Academic Portal

Citation for published version (APA):

Bikanga Ada, M., Stansfield, M., \& Baxter, G. (2017). Using mobile learning and social media to enhance learner feedback: some empirical evidence. Journal of Applied Research in Higher Education, 9(1), 70-90.

https://doi.org/10.1108/JARHE-07-2015-0060

\section{General rights}

Copyright and moral rights for the publications made accessible in the UWS Academic Portal are retained by the authors and/or other copyright owners and it is a condition of accessing publications that users recognise and abide by the legal requirements associated with these rights.

Take down policy

If you believe that this document breaches copyright please contact pure@uws.ac.uk providing details, and we will remove access to the work immediately and investigate your claim. 


\section{Dinerald Junhal of tApplied Research \\ Emerald in tigher Ectucation}

\section{Using Mobile Learning and Social Media to Enhance Learner Feedback: Some Empirical Evidence}

\begin{tabular}{|r|l|}
\hline Journal: & Journal of Applied Research in Higher Education \\
\hline Manuscript ID & JARHE-07-2015-0060.R3 \\
\hline Manuscript Type: & Research Paper \\
\hline Keywords: & $\begin{array}{l}\text { Higher education, Feed-forward, Educator feedback, Mobile Learning, } \\
\text { Social media, Student feedback }\end{array}$ \\
\hline \multicolumn{2}{|l}{} \\
\hline
\end{tabular}




\section{Using Mobile Learning and Social Media to Enhance Learner} Feedback: Some Empirical Evidence

Purpose

The purpose of this paper is to investigate an area of growing importance that is widely recognised in the literature relating to the issue of how to improve ways that assessments and feedback are provided to students within higher education. This paper reports on a study that aimed to explore the views of both educators $(n=70)$ and students $(n=540)$ on feedback and feed-forward at a UK university. The study also investigated their experience and attitudes to social media applications as a means of enhancing access to feedback within the context of mobile learning.

\section{Design/methodology/approach}

The research approach adopted in this study predominately conforms to a quantitative research design though embeds elements of qualitative research via a 'mixed methods' approach. The overall methodology of the paper adheres to an exploratory case study in a higher education environment to identify various issues and approaches that could be addressed or enhanced to aid ways that assessments and feedback are disseminated to students within higher education.

\section{Findings}

Participants' views were sought in relation to students receiving learning materials, as well as feedback from tutors directly to their smartphones and mobile devices. In addition, the study explored possible reasons for students not wanting to use social media and mobile devices for their learning and feedback. Overall, the results indicated a positive attitude on the part of educators and students to using mobile devices and social media applications for teaching and learning purposes.

\section{Research limitations/implications}

The case study presented in this paper draws on findings from one higher educational institution. Further research is required to determine the generalisability of the 
findings to allow comparison of the findings to be undertaken within other higher education institutions.

\section{Originality/value}

The originality of the paper is that it provides detailed empirical evidence and findings that provide several important implications in relation to enhancing the student learning experience and providing considerable improvements to the way that feedback is provided that make it more likely that students will take more notice to feedback and act upon it. This in turn enables educators to better plan and manage their teaching and student experience online and through students' mobile devices. The value of this study is that it explores views of both educators and students, whereas many other previous studies tend to focus on the views of either educators or students.

Keywords: Student feedback, feed-forward, higher education, educator feedback, mobile learning, social media.

\section{Introduction}

A major challenge for educators is in attempting to ensure individuality in the approaches they adopt to teaching and keeping students informed and engaged. Higher education institutions are experiencing changes in relation to how technology is affecting teaching and learning (Baxter et al., 2011). The roles of teachers and learners are shifting away from a traditional emphasis on regulating programmes of study and student activities, towards a change in 'mindset' in which there is an increasing level of student autonomy and collaborative learning (Vermunt, 2007). According to Vermunt (2007, p79) "such changes are essential if we are to help students to become self-regulated and self-motivated learners by the time they leave university". Back in 2001, Prensky argued that education was in danger of becoming 
redundant if it did not change how it utilised different ways of learning for the new generation of students. Prensky (2001) identified the 'digital native' as those students born in or after 1980, whilst 'digital immigrant' were born prior to that revolution and are learning to adapt to their environment. Higher education institutions, already supporting widening participation, reflect those two groups as many students are also from an older generation.

Over a decade on and new forms of teaching, learning and assessment for an interactive world such as massive open online courses (MOOCs), badging, seamless learning, crowd learning, geo-learning, learning from gaming, maker culture, and citizen inquiry, are now being investigated (Sharples et al., 2013). Mobile learning adoption within higher education is still in its relative infancy in terms of using students' own mobile handheld devices within mainstream education.

\section{$\underline{\text { Some educators are trying to improve their teaching and learning through }}$}


that some educators are trying to use to improve teaching and learning (e.g. Redecker et al., 2009; Cochrane, 2010; Lunt and Curran, 2010; Taylor et al., 2010). Social media plays an important role in helping facilitate and promote participatory information sharing, interoperability, user-centred design, and collaboration using social software, sharing content, tagging, social networking, blogs, wikis_and - RSS (Anderson, 2008; Schneckenberg et al., 2011).

\section{Background and literature review}

In the literature, there is evidence of the importance of assessment and feedback in learning and teaching in higher education (Gibbs and Simpson 2004, Nicol and MacFarlane-Dick, 2004; Bloxham and Boyd, 2007). Reports and surveys (for 
example in the UK - National Student Survey, 2010, 2011, 2012; National Union of Students, 2008; Quality Assurance Agency for Higher Education, 2006) show that assessment and feedback have been a significant cause of student dissatisfaction and have continually received the lowest satisfaction score.

There is a growing body of knowledge research-around assessment and feedback aimed at providing a deeper understanding of students' dissatisfaction with their feedback (e.g. Rae and Cochrane, 2008; Hepplestone et al., 2009; Bloxham and Campbell, 2010; Price et al., 2010; Orsmond and Merry, 2011; Price et al., 2011). Some of the reasons for this dissatisfaction are reported as being the lack of timely constructive feedback and lack of one-to-one meetings with the teacher where the assignment and feedback can be discussed (Trowler and Trowler, 2010). This is mainly due to workload issues (Lunt and Curran, 2010; Nicol, 2010) caused by mass higher education. Other issues affecting assessment and feedback include the lack student engagement (Orsmond and Merry, 2009; Handley and Williams, 2011), the lack of dialogue as communication (Rae and Cochrane, 2008; Bloxham and Campbell, 2010; Nicol, 2010; Orsmond and Merry, 2011; Price et al., 2011) and the lack of motivation that can affect feedback, and thus, the student learning process (Orsmond and Merry, 2009).

More specifically, research conducted by Price et al., (2010) indicates that both tutors and students recognize that relationship and dialogue are very important aspects in feedback. However, students feelt frustrated and are less engaged with the written feedback in the absence of dialogue. For example, many students are still unwilling to engage in a dialogue because of being embarrassed or feeling intimidated. This lack of confidence from the part of students undermines their 
learning since they are not getting the support help-needed from tutors is for their work lacking from their tutors-(Bloxham and Campbell, 2010).

Handley et al., (2008) highlight the relational dimension of student engagement with feedback has a great impact on how students receive, interpret and evaluate feedback and how students react to any questions or their misunderstandings. Issues arise in defining the line between student questions to tutors and confrontation, respectful listening and tacit agreement. Other problems highlighted by students include the lack of motivation to engage in dialogue when not being shown interest by staff, when tutors seem unapproachable to them by being 'too busy', tutors always seem to be in a hurry, have 'other things to do' or students' unwillingness to interrupt staff.

While the literature contains examples of assessment and feedback studies, few studies have surveyed students and educators on the key issues around feedback and feed-forward. Most studies have mainly focused on the students' version of the issues. Specific eme-studies have explored educators' version of the issues around assessment and feedback (e.g. Bailey and Gardner, 2010; Harman and McDowell, 2011). Other studies have compared teachers and students perceptions of assessment and feedback (e.g. Carless, 2006; Meyer et al., 2010). One finding among these studies is the divergent understanding of assessment and feedback from both students and educators. In Carless' study, teachers considered that their feedback was useful to the students, but the students did not share this viewtook a differing view. In Meyer et al.'s research, for students, the purpose of assessment was for accountability while teachers saw it as a way to improve learning.

Another area of the study described in this paper involves feed-forward. It is a concept that advocates students be aware of important points in future assessment 
tasks and make use of feedback in everyday learning activities as well as in response to formal assignments (Laurillard, 2002) and which learners can benefit from (Black and Wiliam, 1998; 2007; Race, 2007; Irons, 2008). This concept is also advocated by Price et al., (2010) who highlight that feedback should be "directed at supporting improvements in the next assignment” (p.279). It helps shaping and directing students on how to answer future questions in assignments (Nicol and Macfarlane-Dick, 2006) Feed-forward is being investigated by many authors with the intention of increasing student achievement (Hounsell, 2007; Murtagh, and Baker, 2009). As pointed by Nicol (2010), good quality feedback should provide suggestions on how students could improve their work for future assignment. Feed-forward provides constructive guidance on how to do improve future assignments and together with feedback and provided in a timely manner, feed-forward can foster student learning improvement (Ferrell, 2013). However, formative feedback which is defined as any information, process or activity that speeds up student learning based on comments resulting from their formative or summative assessment (Irons, 2008), is not always recognized by students. Sometimes students are not even aware of a feedback and this could be due to the lack of motivation from teachers in developing the students' skills in learning from feedback.

Li and De Luca (2014) who reviewed 37 empirical studies on assessment and feedback noted that there were few studies on the actual practices of feedback. They recommended exploring various aspects of assessment practices with cross-disciplinary and cross-sections dialogues. They suggested beginning with an investigation of the assumptions and beliefs of stakeholders. Thus, the study reported in this paper aimed to explore the views of both educators and students on feedback, feed-forward, as well as their experience and attitudes to social media applications as a means of enhancing access to feedback within the 
context of mobile learning at a UK university. The UK university was used because it provided a means of convenience sampling which would increase the ease of access to larger numbers of students and educators and potentially provide a higher number of responses which would provide more meaningful results. Participants' views were sought in relation to students receiving learning materials, as well as feedback from tutors directly to their smartphones and mobile devices. In addition, the study explored possible reasons for students not wanting to use social media and mobile devices for their learning and feedback.

\section{Methodology and data collection}

The research questions centred around (i) how can assessments and feedback provided to students within higher education be improved? and (ii) what are the attitudes and experiences of students and educators to using social media applications as a means of enhancing access to feedback within the context of mobile learning? The research methodology adopted in this study predominately conforms $\underline{s}$ to a quantitative research design, although embedding elements of qualitative research via a 'mixed methods' approach. The overall methodology of the paper adhered to an exploratory case study in a higher education environment to identify various issues and approaches that could be addressed or enhanced to aid ways that assessments and feedback are disseminated to students within higher education. This approach was used because it enabled the quantitative components to describe the topics being investigated while the qualitative elements of the mixed method approach brought out the richness of participants' views in a student-centered and educator-centered approach on these phenomena. Furthermore, while measurable variables of the quantitative elements may limit what this study is investigating, the qualitative element allows observing a wider range of phenomena including the complex meanings and processes participants feel and the context in which these occur. There 
were 36 questions in the teaching staff survey and 34 in the students' questionnaire. The questionnaires were made available through the online questionnaire package SurveyMonkey for both the teaching staff member and students. Participation was voluntary and participants were notified of the availability of the questionnaire through email and the questionnaires were not resent. There were two surveys, one for educators and one for students, a copy of the questions are included in Appendix I. There was no limit to the sample as the study wished to gather information from as wider a pool as possible. Data was entered to SPSS18 and treated anonymously.

\section{Results}

\section{Demographic}

Educators $(n=70)$ consisted of 36 males and 31 females. Three skipped the gender question. In terms of age range, most of them belonged to the age range 50-59 (37) and 40-49 (24), with only one from 20-29 age range. Of the 540 students who answered the survey, $32.5 \%$ were males and $67.5 \%$ were females. The age range with the highest number of students was 20-29 (44.3\%), and the lowest was over 60 $(0.7 \%)$

Of the 69 educators who responded to the question regarding their academic status, 63 respondents $(91.3 \%)$ were full-time and 6 respondents were part-time academics. A cross tabulation with the age range showed that the majority of the fulltime academic belonged to the age ranges 40-49 (20) and 50-59 (36). The job title varied and included . There were -50 lecturers, 10 senior lecturers, 4 readers, 3 professors, 2 associate lecturers and 1 teaching fellow. Although each of the participants had various academic roles, modules delivery (e.g. teaching) was the role with the highest percentage $94.2 \%$ (65). In terms of educators' number of years into 
teaching, the mean was 16.60 years $(S D=8.81)$. Of the 537 students who answered the question regarding their student status, $385 \quad(71.7 \%)$ were full-time undergraduates, $57(10.6 \%)$ part-time postgraduates, $48 \quad(8.9 \%)$ part-time undergraduates and 39 respondents (7.3\%) were full-time postgraduates. Out of 532 students who answered the question regarding the teaching methods, $89.1 \%$ took their course via traditional methods (lectures, tutorials and labs), 9.4\% distance learning, $0.6 \%$ mobile learning and $5.8 \%$ of students via other methods or a combination of methods. From the 536 responses concerning their year of study, the majority of respondents were in their third year of study (192) followed by those in their first year (142), second year (117 students), fourth year (76) and fifth year (9 students). A cross tabulation between the year of study and the students' status showed that most students were full-time undergraduates in their third year of studies (159).

\section{On the frequency of feedback}

There were 462 students and 65 educators who answered this question. Figure 1 shows that 'Only after assignment' was selected the most (49.1\%) by students and 'Whenever it is required' by educators. Table 1 lists what students $(n=32)$ think could be the reasons for not receiving feedback and educators' $(n=49)$ reasons for not providing feedback. 
When do you give feedback to students $\%$ When do you get feedback on yo

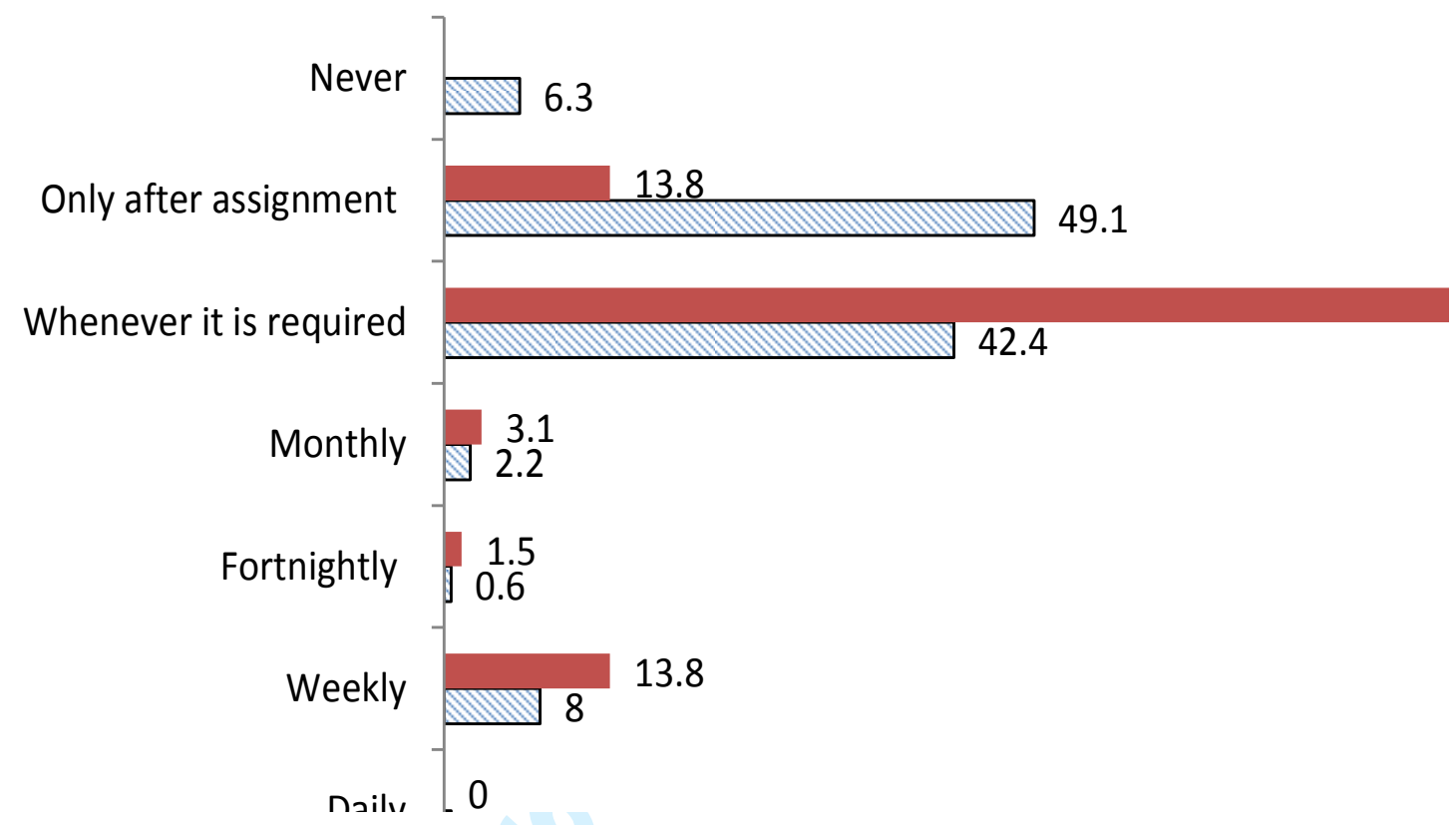

Figure 1: When do students receive feedback on their work vs when do educators give feedback to students

Table 1: Students' reasons for not receiving feedback versus educators' reasons for not giving feedback

\begin{tabular}{|l|l|}
\hline $\begin{array}{l}\text { Students reasons for not receiving } \\
\text { feedback }\end{array}$ & $\begin{array}{l}\text { Educators' reasons for not giving } \\
\text { feedback }\end{array}$ \\
\hline Students have never asked nor been offered & Time \\
\hline Students asked but did not receive it & $\begin{array}{l}\text { Classes too large-/-too many, assignments to } \\
\text { mark }\end{array}$ \\
\hline Online course from external examiners & $\begin{array}{l}\text { No submission of work-/-incomplete student } \\
\text { work }\end{array}$ \\
\hline Scarce and irregular feedback & Students not available at the time of feedback \\
\hline Feedback is only to a specific subject & $\begin{array}{l}\text { Academic misconduct-/-plagiarism with defer } \\
\text { decision }\end{array}$ \\
\hline High students number & Overload of administrative paperwork \\
\hline Teaching staff say they have no time & $\begin{array}{l}\text { The way modules are set up-/-unhelpful } \\
\text { timetable }\end{array}$ \\
\hline Do not know why & Too many classes-/-many campuses \\
\cline { 2 - 2 } & $\begin{array}{l}\text { Students' lack of engagement with the } \\
\text { module and missing classes }\end{array}$ \\
\cline { 2 - 2 } & $\begin{array}{l}\text { Excessive feedback request from students-/ } \\
\text { Feedback requested one or two days before } \\
\text { submission }\end{array}$ \\
\cline { 2 - 2 } & Students don't collect/use feedback \\
\hline
\end{tabular}




\section{On feed-forward: Students vs Educators}

Reluctance/ inability to provide feedback that reflects students' performance-/Ppoor quality of feedback

There were 66 educators and 458 students' responses for this question. A quarter of students never receive feed-forward. If students do not request it, the number rises to more than half. Table 2 shows that most students receive feed-forward comments only if they request it (31\%). Most educators (78.8\%) give feed-forward; One of the two who did not give feed-forward did not know what feed-forward iwas.

Table 2: Do you receive feed-forward (students)? (Feed-forward comments are suggestions that would be helpful in future course works or assignments.)

\begin{tabular}{|c|c|c|c|c|}
\hline \multicolumn{3}{|c|}{ Do you receive feedforward? (Students) } & \multicolumn{2}{|c|}{ Do you receive feed-forward? (staff) } \\
\hline & $\%$ & $\mathrm{~N}$ & & \\
\hline Only if I request & $31 \%$ & 142 & Give feed-forward & $78.8 \%$ \\
\hline Never & 25.3 & 116 & Sometimes & $16.7 \%$ \\
\hline After the module & 16.6 & 76 & If requested & $1.5 \%$ \\
\hline After the class & 11.4 & 52 & \multirow[t]{4}{*}{ Do not give feed-forward } & \multirow[t]{4}{*}{$3 \%$} \\
\hline Weekly & 10.3 & 47 & & \\
\hline Monthly & 3.9 & 18 & & \\
\hline Fortnightly & 1.5 & 7 & & \\
\hline
\end{tabular}

\section{On using comparison in feedback (Educators)}

There were 63 educators who answered that question generating 100 total responses. 'Criterion-referencing (feedback against clear criteria)' was selected the most (90.5\%). It was followed by 'Self-referenced feedback (helps describe the processes or methods students use)' (50.8\%). 'Norm-referenced feedback (compares a student's 
performance to the performance of other students)' was selected 9 times only which gives $9 \%$ of responses or $14.3 \%$ of cases. There were also $2(3.2 \%)$ people who did not know what comparison in feedback meant.

\section{On the focus of the content of feedback: Educators vs students}

A total of 449 students and 65 educators answered this question. According to Figure 2, the least selected option by both educators (36.9\%) and students (15.1\%) was 'why the right answer is correct'.

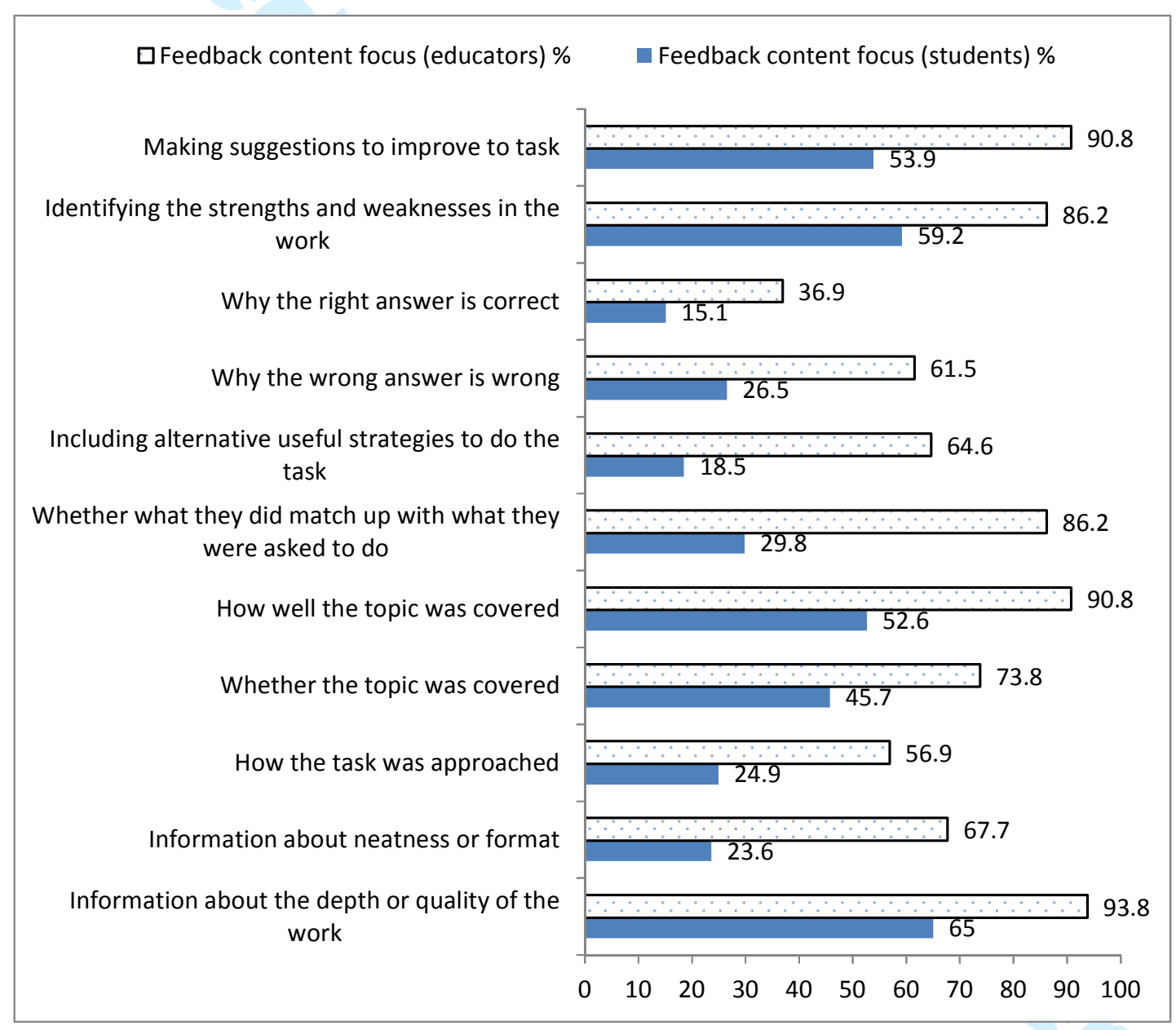

Figure 2: Feedback content focus: Educators vs students 


\section{On feedback method choice opportunities: Educators vs students}

Of the 445 students who answered this question, only $25.1 \%$ said they were given the opportunity to choose the feedback method they prefer. Only $22.2 \%$ of educators gave that opportunity to students. Table 3 reveals the reasons students $(n=115)$ think they are not receiving to choose the feedback method and educators $(n=32)$ not creating these opportunities.

Table 3: Reasons for no choice of feedback methods: Educators vs students

\begin{tabular}{|l|l|}
\hline Students & Educators \\
\hline Have never been asked & $\begin{array}{l}\text { Never been asked-/-never been an } \\
\text { option-/-unsure }\end{array}$ \\
\hline $\begin{array}{l}\text { The lecturers just do not give the opportunity/ } \\
\text { no option to choose }\end{array}$ & Time issues \\
\hline Do not know why & $\begin{array}{l}\text { Conformance to University } \\
\text { Guidelines }\end{array}$ \\
\hline Have never asked & Written feedback works \\
\hline Not being 'told this was an option & Huge number of students \\
\hline Don't receive feedback anyway & $\begin{array}{l}\text { Conformance to task being } \\
\text { undertaken }\end{array}$ \\
\hline Feedback is about lecturers' preferences & $\begin{array}{l}\text { Lack of perceived value } \\
\text { Lack of student engagement }\end{array}$ \\
\hline
\end{tabular}

\section{On student satisfaction with their feedback}

A total of 456 students answered this question. Nearly half the students, $43.4 \%$, have been dissatisfied with their feedback. A high number of students $(n=170)$ explained why they were dissatisfied (Table 4).

Table 4: Students' reasons for being dissatisfied with feedback

\begin{tabular}{|l|}
\hline \multicolumn{1}{|c|}{ Students' reasons for being dissatisfied with feedback } \\
\hline The feedback is too generalised \\
\hline Inaccurate feedback \\
\hline Unconstructive feedback \\
\hline Unhelpful-/-inconsistent (comment sheet are not specific) \\
\hline
\end{tabular}


The length of feedback (feedback is very short)

The lack of depth-/-vagueness of feedback Focus on criticism 'Sometimes it hurts to receive criticism'

Negative feedback-/effort being ignored

Lecturers are unavailable to ask for feedback

Different lecturers $=$ different methods of how assessment should be answered

Difficulty to read hand written feedback

Feedback is not useful due to the timing and feedback approach used

No feedback for students with high mark

Never been told what to expect or what to do-/lack of guidance

Feedback not aligned with assessment criteria/marks

The proportion of females who have been dissatisfied with the feedback received (47\%) is significantly different from males' (34\%).

Traditional (lectures, tutorials and labs) students were more satisfied with their feedback $(55.8 \%)$ than distance learners $(51.2 \%)$ and students being taught using eanother method or a combination of methods (48\%). Full-time undergraduates (46.5\%) have been dissatisfied than other groups. According to figure 3, students who were given the opportunity to choose their feedback methods were most satisfied with their feedback than those who did not have that choice. As shown on figure 4, 60.5\% of students $(n=114)$ who never received feed-forward were more dissatisfied generally than other students; meanwhile those who received feed-forward on a weekly basis were the most satisfied. Students in their early year of studies were more satisfied with the feedback they received than those in the later years of studies. 


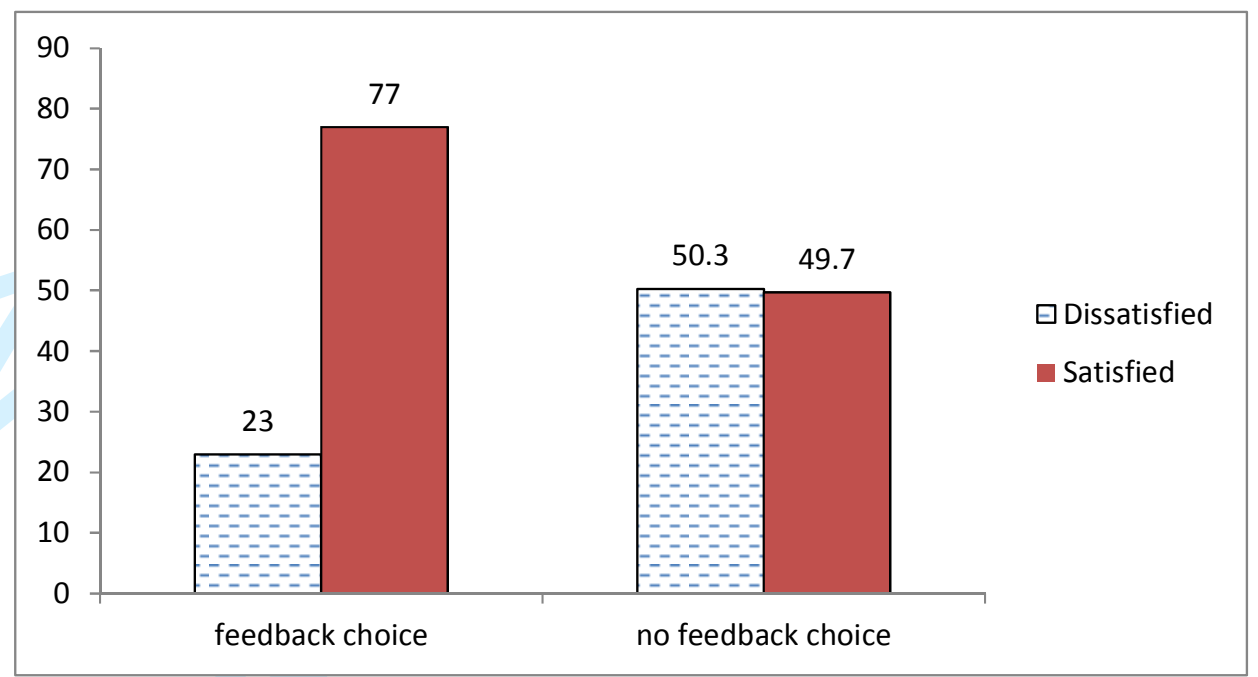

Figure 3: Student dissatisfaction - feedback choice cross-tabulation

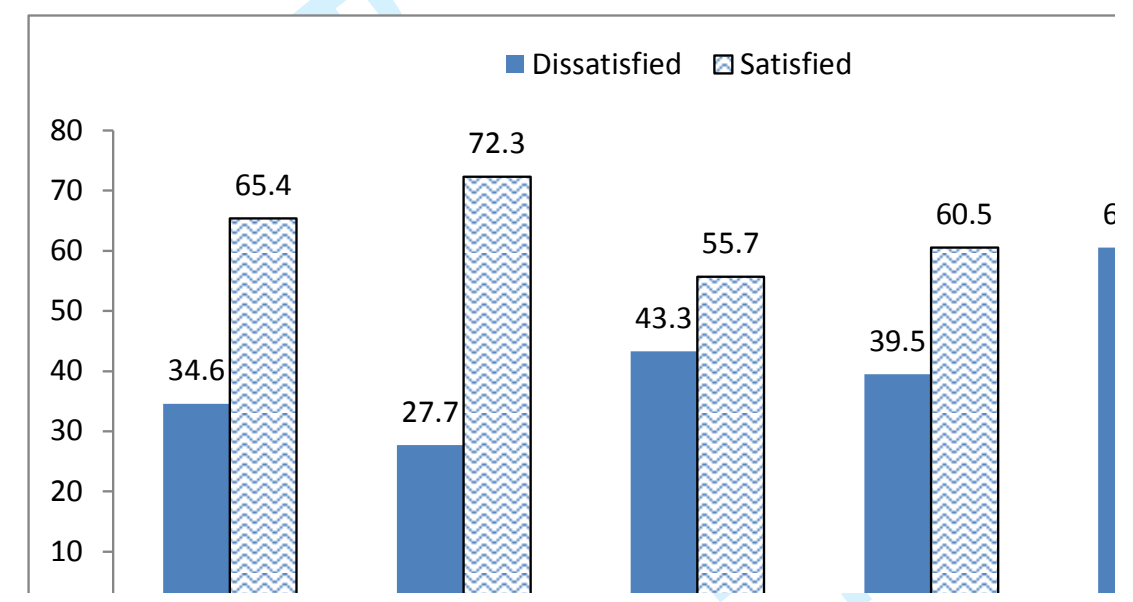

Figure 4: Student dissatisfaction with feedback - feed-forward cross-tabulation

\section{On issues affecting the provision of effective feedback? (Educators)}

For this open-ended question, the answers of 47 educators produced a total of 70 responses. Figure 5 shows that 'Time and workload issues' $(66 \%)$ are the main issues affecting the provision of feedback. 


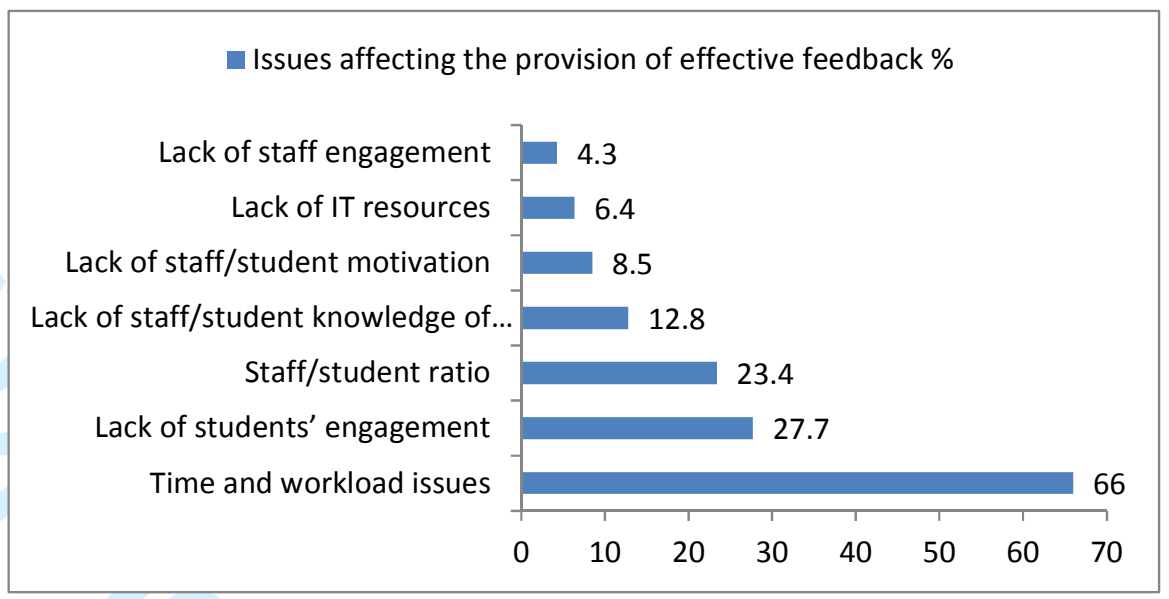

Figure 5: Issues affecting the provision of effective feedback (educators' perceptions)

\section{On feedback methods preference: Educators vs students}

Written feedback is the method that most students already receive. However, if they had a choice, they would prefer receiving feedback via email whereas educators would prefer face-to-face (Table 5).

Table 5: Ranking and means of feedback methods preference: Educators vs students

\begin{tabular}{|l|l|l|l|l|}
\hline Feedback methods & \multicolumn{2}{|l|}{ Students } & \multicolumn{2}{l|}{ Educators } \\
\hline & $\mathrm{R}$ & Mean & $\mathrm{R}$ & Mean \\
\hline Email & $1^{\text {st }}$ & 3.89 & $3^{\text {rd }}$ & 3.22 \\
\hline Face-to-Face & $2^{\text {nd }}$ & 3.88 & $1^{\text {st }}$ & 3.34 \\
\hline Written & $3^{\text {rd }}$ & 3.72 & $4^{\text {th }}$ & 3.17 \\
\hline Blackboard (VLE) & $4^{\text {th }}$ & 3.55 & $2^{\text {nd }}$ & 3.30 \\
\hline Podcast & $5^{\text {th }}$ & 2.19 & $5^{\text {th }}$ & 2.47 \\
\hline SMS & $6^{\text {th }}$ & 2.00 & $9^{\text {th }}$ & 2.05 \\
\hline Videocast & $7^{\text {th }}$ & 1.89 & $6^{\text {th }}$ & 2.40 \\
\hline Blog & $8^{\text {th }}$ & 1.64 & $7^{\text {th }}$ & 2.39 \\
\hline Wikis & $9^{\text {th }}$ & 1.57 & $8^{\text {th }}$ & 2.37 \\
\hline
\end{tabular}

\section{On educators receiving feedback}

There were 458 students and 62 educators who answered this question. Table 6 shows that educators mostly received feedback from their students after the module. Some 
educators $(10.8 \%)$ commented that they also received ongoing (throughout the module/class) feedback from students or when students wanted.

Table 6: On educators receiving feedback from students $(* * *$ denotes option not available)

\begin{tabular}{|l|l|l|}
\hline Question options & $\begin{array}{l}\text { Student give feedback } \\
\text { to educators }\end{array}$ & $\begin{array}{l}\text { Educators receive } \\
\text { feedback }\end{array}$ \\
\hline Whenever it is required & $24.9 \%$ & $* * *$ \\
\hline Throughout module/class & $* * *$ & $10.8 \%$ \\
\hline After the module & $46.3 \%$ & $96.8 \%$ \\
\hline After the class & $3.5 \%$ & $32.3 \%$ \\
\hline At the end of the course & $* * *$ & $21 \%$ \\
\hline Never & $24.5 \%$ & $* * *$ \\
\hline
\end{tabular}

Nearly a quarter of students (24.5\%) never gave feedback to their lecturers/-tutors/ supervisors, and 28 of the 65 students who explained why they did not give feedback to their tutors, said that they were never asked, the opportunity has never arisen; they did not know how to tell them, and they were not aware that it could be done. Some students were also aware of the lecturers being under pressure.

Other reasons for students for not giving feedback to educators included the present module feedback questionnaire provides students little opportunity to give detailed and specific feedback, Ss students do not feel comfortable like criticising or correcting teaching staff, students fear of retribution from the lecturer, and some students do not know when and how to provide lecturers with feedback.

\section{On Social Media Experience}

Participants were asked which of the following social media applications they use at the University, for teaching, learning and research purposes. There were 40 educators and 314 students who answered this question. Table 7 showed that the most used social media application was YouTube for educators and Facebook for students. The 
results also showed that whilst students from the School of Computing mostly used YouTube and Wikis, the remaining schools preferred Facebook.

Table 7: Most used social media applications for learning and teaching (*** denotes option not available)

\begin{tabular}{|c|c|c|c|c|c|c|}
\hline Social media applications & Rank & $\%$ & $\mathbf{N}$ & Rank & $\%$ & $\mathbf{N}$ \\
\hline & \multicolumn{3}{|c|}{ Teaching staff } & \multicolumn{3}{|c|}{ Students } \\
\hline YouTube & $1^{\text {st }}$ & 75 & 30 & $2^{\text {nd }}$ & 50.6 & 159 \\
\hline Blogs & $2^{\text {nd }}$ & 37.5 & 15 & $6^{\text {th }}$ & 14.3 & 45 \\
\hline Skype & $2^{\text {nd }}$ & 37.5 & 15 & $7^{\text {th }}$ & 7.6 & 24 \\
\hline Facebook & $3^{\text {rd }}$ & 32.5 & 13 & $1^{\mathrm{st}}$ & 63.1 & 198 \\
\hline Linkedln & $3^{\text {rd }}$ & 32.5 & 13 & $8^{\text {th }}$ & 7.3 & 23 \\
\hline Wikis & $4^{\text {th }}$ & 25 & 10 & $3^{\text {rd }}$ & 28 & 88 \\
\hline Twitter & 5 th & 22.5 & 9 & 5 th & 17.2 & 54 \\
\hline GoogleMaps & $5^{\text {th }}$ & 22.5 & 9 & $4^{\text {th }}$ & 22 & 69 \\
\hline Yammer & $5^{\text {th }}$ & 22.5 & 9 & $11^{\text {th }}$ & 2.9 & 9 \\
\hline Camtasia Relay & $6^{\text {th }}$ & 17.5 & 7 & $* * *$ & $* * *$ & $* * *$ \\
\hline Use Mobile Instant Messaging (Mobile IM) & $* * *$ & $* * *$ & $* * *$ & $9^{\text {th }}$ & 4.1 & 13 \\
\hline Flickr & $7^{\text {th }}$ & 15 & 6 & $10^{\text {th }}$ & 3.2 & 10 \\
\hline
\end{tabular}

Twenty four educators answered the open-ended question as to why they do not use social media applications, and most of them (22.6\%) had 'no skills/-lack of training'. 'No time to learn/-develop' and 'Lack of perceived usefulness' shared the second position with $19.4 \%$ each. 'Not suitable for subject' came third with $12.9 \%$. 'Lack of confidence/-uncomfortable' scored 6.5\%. 'Legal implication concerns (inflexible regulations)', 'Lack of motivation' and 'separate private/-professional life' had 3.2\% of total responses.

Of the 130 students who responded more than half of the answers against the use of social media included: 'Don't know about them/-don't trust them/-don't use/ don't like/-age/-not interested' and the 'lack of perceived value'. Those who use social media applications where asked how often they access it on the devices listed in the questionnaire. Figure 6 shows that educators used their home computer the most on a daily basis $(45.7 \%)$ to access social media tools while students used their laptops (52.4\%). The second most used device on a daily basis for both groups was their own 
mobile phones.

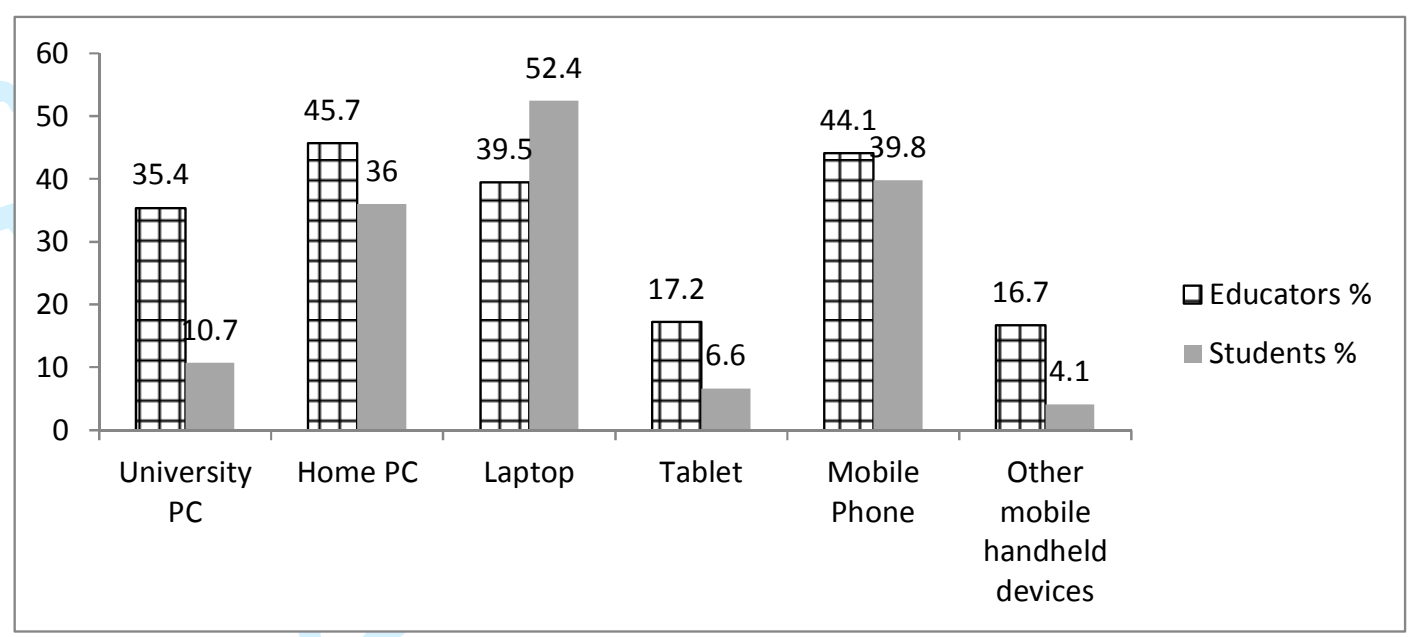

Figure 6: Most used devices for social media applications access on a daily basis

Table 8 which shows the frequency of social media use for teaching and learning activities reveals that the majority of the respondents in both groups never used social media for teaching and learning activities because they 'don't know' or they did not see the 'perceived pedagogical value'. Some of them also said they would never consider using it. Nevertheless, others would consider using social media for 'Interaction with students (professional/-Facebook/-Blog), 'Making calls (Skype), 'Test-/-quiz-/-calendars/-SMS'. On the other side, some students would consider using these applications for game-based learning, calendars, uploading learning material, discussion with peers, file sharing and test and quizzes.

Table 8: Frequency of social media for teaching and learning activities

\begin{tabular}{l|l|l|l} 
Frequency & Rank & Students & Teaching staff \\
\hline $\begin{array}{l}\text { Several times } \\
\text { per day }\end{array}$ & 1 st & Text messaging & Calendar \\
\hline Daily & 1 st & $\begin{array}{l}\text { Interaction with students } \\
\text { (chat) }\end{array}$ & $\begin{array}{l}\text { Interaction with students } \\
\text { (chat) }\end{array}$ \\
\hline & $2^{\text {nd }}$ & Text messaging & Discussion with peers \\
\hline & $3^{\text {rd }}$ & Discussion with peers & $\begin{array}{l}\text { File sharing (pictures, } \\
\text { video, and documents) }\end{array}$
\end{tabular}




\begin{tabular}{l|l|l|l|} 
Weekly & $1^{\text {st }}$ & $\begin{array}{l}\text { File sharing (pictures, video, } \\
\text { and documents) }\end{array}$ & $\begin{array}{l}\text { Uploading learning } \\
\text { materials }\end{array}$ \\
\hline Fortnightly & $2^{\text {nd }}$ & $\begin{array}{l}\text { Downloading learning } \\
\text { material }\end{array}$ & $\begin{array}{l}\text { File sharing (pictures, } \\
\text { video, and documents) }\end{array}$ \\
\hline & $1^{\text {st }}$ & Discussion with peers & $\begin{array}{l}\text { Interaction with students } \\
\text { (chat) }\end{array}$ \\
\hline & 2 nd & $\begin{array}{l}\text { File sharing (pictures, video, } \\
\text { and documents) }\end{array}$ & $\begin{array}{l}\text { File sharing (pictures, } \\
\text { video, and documents) }\end{array}$ \\
\hline Monthly & $3^{\text {rd }}$ & Test/quizzes & Making calls (e.g. Skype) \\
\hline & $1^{\text {st }}$ & Test/quizzes & Making calls (e.g. Skype) \\
\hline & $2^{\text {nd }}$ & $\begin{array}{l}\text { File sharing (pictures, video, } \\
\text { and documents) }\end{array}$ & Recording video \\
\hline & $3^{\text {rd }}$ & Discussion with peers & Test/quizzes
\end{tabular}

When asked how acceptable it would be for the University to contact students via social media applications available on the institution's VLE for learning purposes (e.g. Feedback), of the 59 educators and 426 students' responses to this question, $50.9 \%$ of educators and $45 \%$ of students said they would find 'acceptable' and 'very acceptable'. Figure 7 unveils a high percentage of neutral responses, 39\% for educators and $35.7 \%$ for students., indieating that there were no strong opposition to that idea.

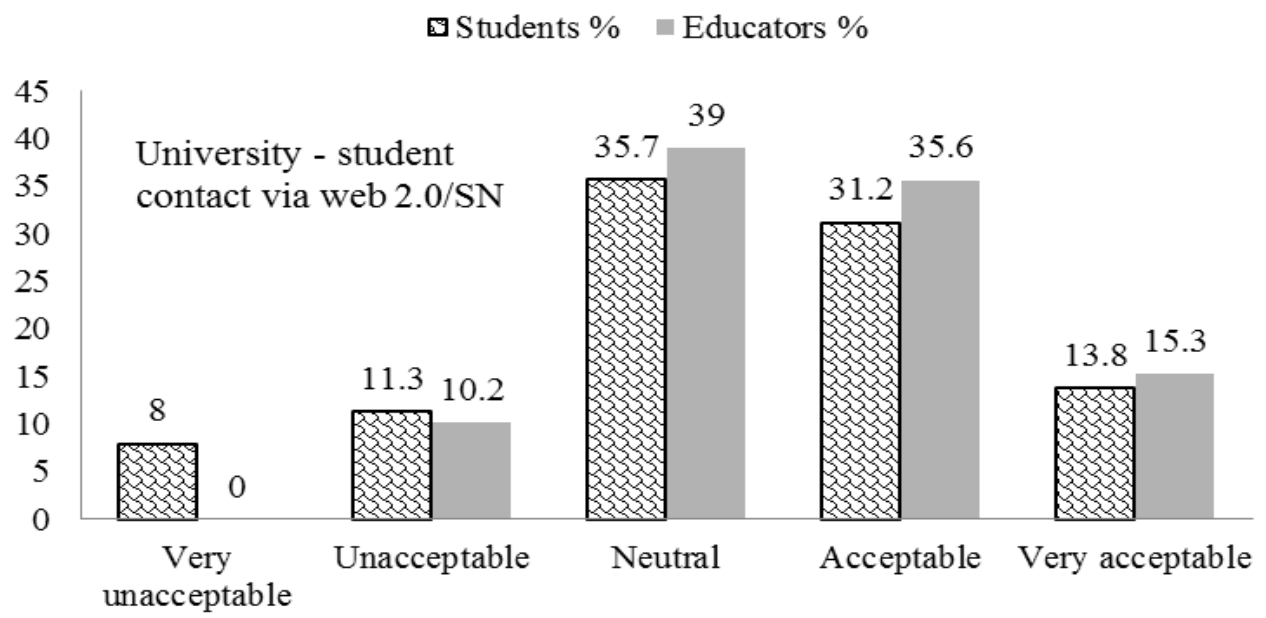

Figure 7: University contacts students via social media 
The question regarding the usefulness of such contact received 60 responses from educators and 427 from students. Figure 8 below shows that whilst most educators $(43.3 \%)$ and students $(48.8 \%)$ would find it 'useful' and 'very useful' communicating with students via social media applications available on the VLE for learning purposes (e.g. Feedback), there is also a the-high percentage of neutral responses (38.3\% for teaching staff and $31.9 \%$ for students).-also showed that there was alse less aversion to that idea.

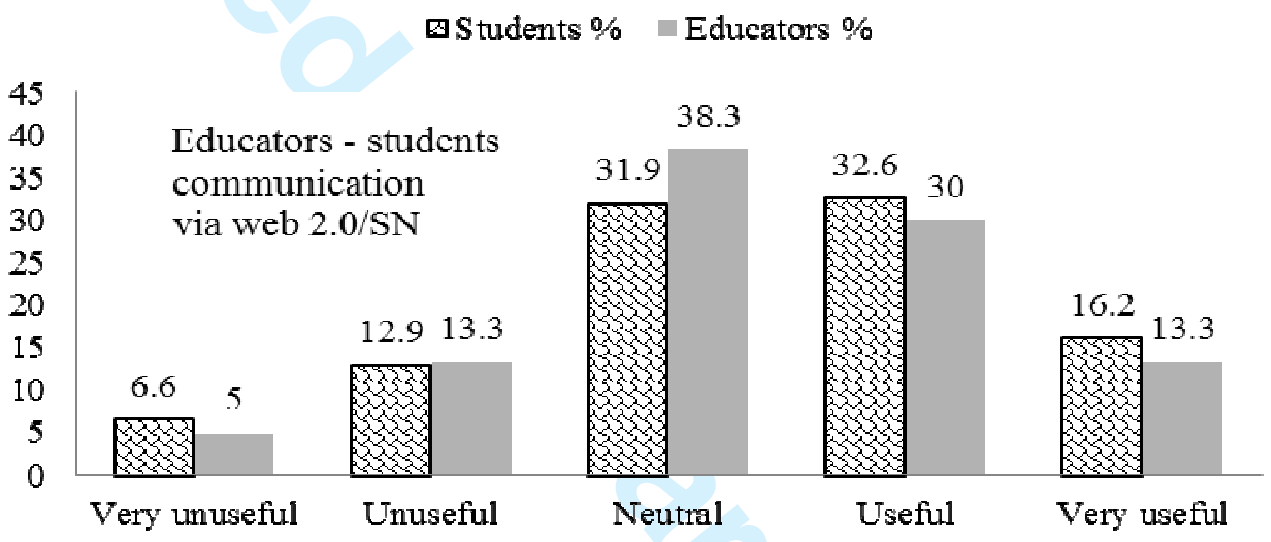

Figure 8: Educators - students' communication via social media for teaching and learning purpose

\section{Discussion}

According to Evans (2013), who reviewed 460 articles on assessment feedback from 2000 to 2012, most of assessment problems derive from these facts that the student population has increased in higher education, the unit of resource is being stretched and the growing pressure on academic staff regarding traditional assessment. Due to the limitation in resources and the ever growing numbers of students in higher education, the provision of feedback that is prompt, detailed, structured, relevant and clear provides a significant increase in workload for educators and contributes to further disappointment experienced by students (Nicol et al., 2014). The study 
reported in this paper found that a major issue affecting feedback provision on the part of educators was time and workload, and that students had not been offered feedback.

There are many principles that guide educators on the type of feedback that is necessary to enhance student learning (Gibbs and Simpson, 2004; Nicol, 2009, Henderson and Phillips, 2014), however, Henderson and Phillips argue that without the use of technology, applying these principles would be time consuming and impractical in large classes. Learners can be engaged with their feedback by varying the feedback delivery method including using technology such as social media and mobile devices. In order to engage learners, using mobile technology and social media available on these technologies, which students already engage with on a daily basis, may better foster student engagement with feedback. This is because mobile learning activities, designed carefully, can engage students to participate in them (Bradley et al., 2010) and change them from passive to be actively involved in their learning task (Wang et al., 2009). The study reported in this paper found that students who had greater say in their feedback method were the most satisfied and that over $50 \%$ of students considered the use of social media for teaching and learning purposes to be either useful or very useful, with less than $20 \%$ having some kind of negative view. Carless (2006, p. 230) highlighted the need of "assessment dialogues" between students and teachers that will enable the clarification of what is expected from both parties in terms of assessment and opportunities for improvement. When students have a stake in the assessment and feedback process, they become more engaged. For example, a JISC report (Ferrell, 2013) highlighted the success of a project that considered students as partners in relation to the design and feedback practice.

In relation to the issue of student feedback, the vast majority of educators do not give their students an opportunity to choose their preferred method of feedback. 
This lack of choice and variation has been highlighted as an issue in the literature (e.g. Walker, 2009; Price et al., 2010). Findings from the study reported in this paper found that fif students were given the choice, they would prefer receiving feedback via email as opposed to face-to-face (verbal) feedback that educators favoured. This finding is in contrast to UK National Union of Students' (2012) results that showed that students wanted more verbal feedback. The preference of email could be attributed to the fact that verbal face-to-face feedback can be forgotten quickly, whilst feedback received in written form via email can be revisited and reread many times. The ability for students to receive effective feedback could be compounded by the fact that some students may be avoiding face-to-face feedback with their educator due to a situation that according to Price at al. (2007), there being a tendency for there to be a monologue process than dialogue during tutor/student contact and, as a result, some students avoid voluntarily meeting the tutor for their feedback. Furthermore, some students may lack confidence and become reluctant to engage in a dialogue because of being embarrassed or feeling intimidated (Bloxham and Campbell, 2010). The study reported in this paper showed that those students who were provided feedforward were also the most satisfied. Although the number of educators who give feed-forward to their students is high, many still do not provide it. Furthermore, many students receive feed-forward only if they request it. It implies that if they did not ask for it, more than half $(56.3 \%)$ would not receive it. Some studies have identified modularisation as one of the causes because it limits the scope for assessment practices that feed-forward with Handley et al., (2008) affirming that modularization influences students' sense of progression.

One of the main issues for a modern advanced learner is to receive feedback that is timely and can be used for their next assignment or before the submission of 
their current assignment. The finding echoes those found in a JISC report on an assessment programme that ran between 2011 and 2014 (Ferrell, 2013) which suggests the development of online systems that enable more immediate feedback as a possible means towards addressing some of the issues relating to assessment and feedback that students face.

Overall the study reported in this paper found that there was a positive attitude on the part of educators to consider using mobile learning and social media applications for teaching and learning. With sufficient technical support and adequate training, educators might be given the opportunity to start using mobile learning/social media technologies for their teaching and to enhance the student learning experience. However, some educators are reluctant to embrace new forms of teaching that are different from the traditional and conventional ways they have mastered over many years. That reluctance has also been highlighted in previous studies (Gong et al., 2004; Arrigo et al., 2010). In addition, many educators may face issues such as a lack of time to learn and develop new skills (Gong et al., 2004; Dykes and Knight, 2012; Fritschi and Wolf, 2012; Hylén, 2012) which could be compounded by a lack of motivation. Moerschell's (2009) work showed that the lack of motivation influences the attitude to learn and change teaching patterns in embracing new learning technologies. Some students are also reluctant to embrace new forms of learning that might be different to the traditional and conventional ways they adopt for their courses.

The results of the study reported in this paper show that students are demonstrating a positive attitude to using mobile learning and social media applications for learning which echoes similar findings in a study by Bradley and Holley (2010). Students appear to be adapting the use of their mobile devices for 
learning purposes to fulfil their individual learning needs, as well as enhance their student learning experience. They use the features available on their smartphones to perform a number of learning activities including mobile web surfing, reading email, sharing texts/notes and documents, accessing learning and reading material, as well as participating in peer discussion etc. As a result this provides a key opportunity for educators to give their students more choice as to how they receive timely and effective feedback and feed-forward which might better motivate and engage them in their studies.

\section{Conclusions and future directions}

The purpose of this study was to explore the perception of educators and students on the areas of using social media and mobile devices in order to address key issues surrounding feedback and feed-forward within the context of higher education. The paper has presented interesting and relevant findings from for one University within the UK. In addition, the study explored possible reasons for students' avoidance not wanting toof use social media and mobile devices for their learning and feedback. To conclude, $\Theta$ overall, the results indicated a positive attitude on the part of educators and students to using mobile devices and social media applications for teaching and learning purposes. Initial findings have shown that there is a need to explore the use of mobile learning and social media further in order to better improve the quality and effectiveness of feedback (and feed-forward) that students receive which has consistently been raised as a concern across many studies and surveys both within the UK and globally.

$\underline{\text { In terms of limitations and future research, Ffindings and their implications }}$ discussed in this paper were based on one study that explored the views of students and educators in one university in the UK. Whilst findings do hold some promise in 
that, uncovering ways to improve the dialogue and communication between students and educators through social media and mobile learning could be beneficial in terms of student engagement and motivation with feedback, they cannot be generalised. The next stage of the research is to extend the work reported in this paper to include other higher education institutions in conducting in-depth qualitative studies with educators and students in order to find out more about their views and thinking, as well as enable comparisons to be undertaken.

\section{References}

Anderson, P. (2008), "What is Web 2.0? Ideas, technologies and implications for education", JISC Technologies \& Standards Watch, available at: http://www.jisc.ac.uk/media/documents/techwatch/tsw0701b.pdf (accessed 17 July 2015).

Arrigo, M., Di Giuseppe, O., Fulantelli, G., Gentile, M., Merlo, G., Seta, L., and Taibi, D. (eds) (2010), "MOTILL: Mobile Technologies in Lifelong Learning - Best Practices" Palermo, Italian National Research Council - Institute for Educational Technology, available at: https://www.academia.edu/360359/MOTILL_Mobile_Technologies_in_Lifelong_Lea rning_Best_Practices (accessed 25 August 2015).

Bailey, R. and Garner, M. (2010), "Is the feedback in higher education assessment worth the paper it is written on? Teachers' reflections on their practices", Teaching in Higher Education. Vol 15 No 2, pp. 187-198.

Baxter, G.J., Connolly, T.M., Stansfield, M.H., Tsvetkova, N. and Stoimenova, B. (2011), "Introducing Web 2.0 in Education: A Structured Approach Adopting a Web 2.0 Implementation Framework". 7th International Conference on Next Generation Web Services Practices (NWeSP), 20th-21st October, Salamanca, Spain, pp. 499-504, Print ISBN: 978-1-4577-1125-1

Black, P. and Wiliam, D. (1998). Assessment and Classroom Learning. Assessment in Education: Principles, Policy \& Practice 5, no. 1, pp.7-74.

Black, P., \& Wiliam, D. (2007). Large-scale assessment systems: Design principles drawn from international comparisons. Measurement: Interdisciplinary Research and Perspectives, 5(1), pp.1-53.

Bloxham, S. and Campbell, L. (2010), "Generating dialogue in assessment feedback: Exploring the use of interactive coversheets", Assessment \& Evaluation in Higher Education Vol 35, No 3, pp. 291-300. 
Bloxham, S. and Boyd, P. (2007), Developing effective assessment in higher education: A practical guide. Maidenhead: Open University Press, available at: http://www.mhc.mcgraw-hill.co.uk/openup/chapters/9780335221073.pdf (accessed 20 august 2015).

Bradley, C. and Holley, D. (2010), "How students in Higher Education use their mobile phones for learning", in Montebello, M, Camilleri, V and Dingli, A (Eds.), Proceedings of mLearn 2010: The 9th International Conference on Mobile Learning in Valetta, Malta: University of Malta, pp. 232-239.

Bradley, C., Weiss, M., Davies, C., and Holley, D. (2010). A little less conversation, a little more texting please - A blended learning model of using mobiles in the classroom. Paper presented at the 5th International Blended Learning Conference, 1617 June 2010.

Carless, D, (2006), "Differing perceptions in the feedback process", Studies in Higher Education, Vol 31 No 2 pp. 219-33.

Carless D. (2006). Differing perceptions in the feedback process. Studies in Higher Education, Vol. 31, No. 2, April 2006, pp. 219-233.

Cochrane, T. D. (2010), "Exploring mobile learning success factors", ALT-J Research in Learning Technology, Vol 18 No 2, pp. 133-148.

Dykes, G. and Knight, H. R. (2012), "Mobile learning for teachers: Exploring the Potential of Mobile Technologies to Support Teachers and Improve Practice in Europe", Teacher Focus, UNESCO Working Paper Series on Mobile Learning, available at: http://unesdoc.unesco.org/images/0021/002161/216167E.pdf (accessed 20 May 2015)

Evans, C. (2013). Making sense of Assessment Feedback in Higher Education. Review of Educational Research, 83(1), pp.70-120.

Ferrell, G. (2013). Supporting assessment and feedback practice with technology: from tinkering to transformation. Jisc. Available at: http://repository.jisc.ac.uk/5450/4/Jisc_AF_Final_Synthesis_Report_Oct_2013_v2.pd $\mathrm{f}$

Fritschi, J., and Wolf, M. A. (2012), "Mobile learning for teachers: Exploring the Potential of Mobile Technologies to Support Teachers and Improve Practice in North America." Teacher Focus, UNESCO Working Paper Series on Mobile Learning, available at: http://unesdoc.unesco.org/images/0021/002160/216084e.pdf (accessed 20 June 2015)

Gibbs, G., and Simpson, C. (2004), "Conditions under which assessment supports students' learning", Learning and Teaching in Higher Education, Vol 1 pp. 3-31, available at: https://www.itl.usyd.edu.au/assessmentresources/pdf/Gibbs\%20and\%20Simpson.pdf (accessed 20 May 2015) 
Gong, M., Xu, Y., and Yu, Y. (2004), “An enhanced technology acceptance model for web-based learning”, Journal of Information Systems Education, Vol 15 No 4, pp. 365-374, available at: http://iris.nyit.edu/ kkhoo/Spring2008/Topics/TAM/EnhancedTech._JournalInfo.pdf (accessed 15 May 2015)

Handley, K., Price, M., and Millar, J. (2008), "Engaging Students with Assessment Feedback: Final Report for FDTL5 Project 144/03", Oxford Brookes University: Oxford, available at: http://www.brookes.ac.uk/aske/documents/FDTL_FeedbackProjectReportApril2009.p df (accessed 12 May 2015)

Handley, K., and Williams, L. (2011), "From copying to learning: using exemplars to engage students with assessment criteria and feedback" Assessment \& Evaluation in Higher Education, Vol 36 No 1, pp. 95-108.

Harman, K. and McDowell, L. (2011), "Assessment talk in design: the multiple purposes of assessment in HE", Teaching in Higher Education, Vol 16 No 1, pp. 4152.

Henderson, M., and Phillips, M. (2014). Technology enhanced feedback on assessment. Paper presented at the Australian Computers in Education Conference 2014, Adelaide, SA.

Hepplestone, S., Parkin, H., Holden, G., Irwin, B. and Thorpe, L. (2009), "Enhancing Learning Through Technology Research Project Report 08/09 Technology, Feedback, Action!: The impact of learning technology upon students' engagement with their feedback", available at: http://evidencenet.pbworks.com/f/TFA_Final_Report.pdf (accessed 12 May 2015).

Hounsell, D. (2007), “Towards a more sustainable feedback to students", in Boud, D. and Falchikov, N., Rethinking Assessment in Higher Education: Learning for the longer term, Routledge, London, UK, pp.101-113.

Hylén, J. (2012), "Turning on mobile learning in Europe: Illustrative Initiatives and Policy Implications", Teacher Focus, UNESCO Working Paper Series on Mobile Learning, available at: http://www.unesco.org/new/en/unesco/themes/icts/m4ed/mobile-learningresources/unescomobilelearningseries/ (accessed 20 July 2015)

Irons, A. (2008), Enhancing Learning through Formative Assessment and Feedback. Key Guides for Effective Teaching in Higher Education; Routledge

Laurillard, D. (2002), Rethinking university teaching: A Conversational framework for the effective use of learning technologies. RoutledgeFalmer, London, UK.

Li, J., and R. De Luca. (2014), Review of Assessment Feedback. Studies in Higher Education 39 (2), pp. 378-393. 
Lunt, T. and Curran, J. (2010), "Are you listening please? The advantages of electronic audio feedback compared to written feedback", Assessment \& Evaluation in Higher Education, Vol 35 No 7, pp. 759-769.

Meyer, L. H., Davidson, S., McKenzie, L., Rees, M., Anderson, H., Fletcher, R. and Johnston, P. M. (2010), "An Investigation of Tertiary Assessment Policy and Practice: Alignment and Contradictions", Higher Education Quarterly, Vol 64 No 3, pp. 331350 .

Moerschell, L. (2009), "Resistance to Technological Change in Academia", Current Issues in Education, Vol 11 No 6, available at: cie.asu.edu/ojs/index.php/cieatasu/article/download/1578/622 (accessed 10 April 2015)

Murtagh, L. and Baker, N. (2009), "Feedback to feed forward: Student response to tutors written comments on assignments", Practitioner Research in Higher Education, Vol 3 No 1, pp. 20-28.

National Student Survey (2010) available at: http://www.hefce.ac.uk/lt/nss/results/2010/ (accessed 19 September 2015).

National Student Survey (2011) available at: http://www.hefce.ac.uk/lt/nss/results/2011/ (accessed 19 September 2015).

National Student (2012), available at: http://www.hefce.ac.uk/lt/nss/results/2012/ (accessed 19 September 2015).

National Union of Students (2008), "Student Experience Report", available online at: http://www.nus.org.uk/PageFiles/4017/NUS_StudentExperienceReport.pdf (accessed 19 December 2013).

National Union of Students (2012), "Student Experience Research 2012 Part 1: Teaching and Learning. Student experience research to gain insight into the quality of the learning experience”, available at: http://www.nus.org.uk/PageFiles/12238/2012_NUS_QAA_Teaching_and_Learning.p df (accessed 20 February 2014).

Nicol, D. and Macfarlane-Dick, D. (2004), "Rethinking Formative Assessment in HE: a theoretical model and seven principles of good feedback practice", available at: http://www.enhancementthemes.ac.uk/docs/workshop/rethinking-formativeassessment-a-theoretical-model-and-seven-principles-of-good-feedback-practicepaper.pdf?sfvrsn=24 (accessed 10 September 2015).

Nicol, D. and Macfarlane-Dick, D. (2006) Formative Assessment and Self-Regulated Learning: A Model and Seven Principles of Good Feedback Practice, Studies in Higher Education 31(2): 199-218. Available at: http://ttt.strath.ac.uk/REAP/public/Resources/DN_SHE_Final.pdf 
Nicol, D. (2009). Assessment for Learner Self-Regulation: Enhancing Achievement in the First Year Using Learning Technologies. Assessment \& Evaluation in Higher Education, 34(3), p335-352.

Nicol, D. (2010), "From monologue to dialogue: improving written feedback processes in mass higher education", Assessment \& Evaluation in Higher Education, Vol 35 No 5, pp. 501-517.

Nicol, D., A. Thomson, and C. Breslin. (2014). Rethinking Feedback Practices in Higher Education: A Peer Review Perspective. Assessment \& Evaluation in Higher Education 39 (1), pp. 102-122.

Orsmond, P. and Merry, S. (2009), "Processing tutor feedback: a consideration of qualitative differences in learning outcomes for high and non-high achieving students", Paper presented at the Fostering Communities of Learners, 13th EARLI Conference, Amsterdam, 25-29 August 2009, available online at: http://www.psy.gla.ac.uk/ steve/rap/docs/orsmond09.pdf (accessed 25 July 2013).

Orsmond, P. and Merry, S. (2011), "Feedback alignment: effective and ineffective links between tutors' and students' understanding of coursework feedback", Assessment \& Evaluation in Higher Education, Vol 36 No 2, pp. 125 - 136.

Prensky, M. (2001), "Digital Natives Digital Immigrants", From On the Horizon (NCB University Press, 9(5), October 2001), available at: http://www.albertomattiacci.it/docs/did/Digital_Natives_Digital_Immigrants.pdf (accessed 20 July 2015)

Price, M., Handley, K. Millar, J. and Den Outer, B. (2007), "Report on Case Studies conducted for the FDTL5 Project: Engaging Students with Assessment Feedback", Oxford Brookes University, available at: https://wiki.brookes.ac.uk/download/attachments/27656251/FDTL+Feedback+Case+ Study+Report+$\underline{+ \text { November }+2007 . p d f ? \text { version }=1 \& \text { modificationDate }=1211204808000}$ (accessed 24 June 2014).

Price, M., Handley, K., Millar, J. and O'Donovan, B. (2010), "Feedback: all that effort but what is the effect?", Assessment \& Evaluation in Higher Education, Vol 35 No 3, pp. 277- 289.

Price, M., Handley, K. and Millar, J. (2011), "Feedback: focusing attention on engagement", Studies in Higher Education, Vol 36 No 8, pp. 879-896.

Quality Assurance Agency for Higher Education. (2006), "Code of practice for the assurance of academic quality and standards in higher education: Section 6: Assessment of students - September 2006", The Quality Assurance Agency for Higher Education, available at: http://dera.ioe.ac.uk/9713/2/COP_AOS.pdf (accessed 11 September 2015).

Race, P. (2007). The Lecturer's Toolkit: A Practical Guide to Learning, Teaching \& Assessment, $3^{\text {rd }}$ ed. London and New York: Routledge. 
Rae, A. M. and Cochrane, D. K. (2008), "Listening to students: How to make written assessment feedback useful", Active Learning in Higher Education, Vol 9 No 3, pp. $217-230$.

Redecker, C., Ala-Mutka, K., Bacigalupo, M., Ferrari, A. and Punie, Y. (2009), "Learning 2.0: the impact of Web 2.0 innovations on education and training in Europe", available at: http://ftp.jrc.es/EURdoc/JRC55629.pdf (accessed 19 September 2015).

Sharples, M., McAndrew, P., Weller, M., Ferguson, R., FitzGerald, E., Hirst, T. and Gaved, M. (2013), "Innovating Pedagogy 2013. Open University Innovation Report 2", Milton Keynes: The Open University, available at: http:/www.open.ac.uk/iet/main/sites/www.open.ac.uk.iet.main/files/files/ecms/webcontent/Innovating_Pedagogy_report_2013.pdf (accessed 15 September 2015).

Schneckenberg, D., Ehlers, U. and Adelsberger, H. (2011), "Web 2.0 and Competence Oriented Design of Learning - Potentials and Implications for Higher Education", British Journal of Educational Technology, Vol 42 No 5, pp. 747-762.

Taylor, J. D., Dearnley, C. A., Laxton, J. C., Coates, C. A., Treasure-Jones, T., Campbell, R. and Hall, I. (2010), "Developing a mobile learning solution for health and social care practice", Distance Education, Vol 31 No 2, pp. 175-192.

Trowler, V. and Trowler, P. (2010), "Student engagement evidence summary", The Higher Education Academy, available at: https://www.heacademy.ac.uk/sites/default/files/studentengagementevidencesummary _1.pdf (accessed June 2015).

Vermunt, J. D. (2007), "The power of teaching-learning environments to influence student learning", in Entwistle, N. and Tomlinson, P. (Eds.), Student learning and university teaching, British Journal of Educational Psychology Monograph Series II, 4, pp. 73-90.

Walker, M. (2009), “An investigation into written comments on assignments: Do students find them usable?", Assessment \& Evaluation in Higher Education, Vol 34 No 1, pp. 67-78.

Wang, M., Shen, R. Novak, D. and Pan, X. (2009). The impact of mobile learning on students' learning behaviours and performance: Report from a large blended classroom. British Journal of Educational Technology, vol. 40, issue 4, pp. 673-695. 


\section{Appendix I}

\section{Fact Findings Surveys}

\begin{tabular}{|c|c|}
\hline Questions & Answer options \\
\hline 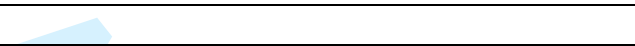 & Demographic \\
\hline What is you gender? & Male, Female \\
\hline Please select the age range you fall between? & $\begin{array}{l}\text { (students) under 20, 20-29, 30-39, 40-49, 50-59, 60+ } \\
\text { (Educators) 20-29, 30-39, 40-49, 50-59, 60-69, 70+ }\end{array}$ \\
\hline $\begin{array}{l}\text { What is your current academic job title? } \\
\text { (Select more than one if } \\
\text { applicable)(educators) }\end{array}$ & $\begin{array}{l}\text { Professor, Senior Lecturer, Reader, Lecturer, Senior } \\
\text { Research Fellow, Research Fellow, Research } \\
\text { Associate, Teaching Fellow, Associate Lecturer, } \\
\text { Research Assistant }\end{array}$ \\
\hline $\begin{array}{l}\text { What roles(s) do you currently play in relation } \\
\text { to teaching and learning? (Select more than } \\
\text { one if applicable) (educators) }\end{array}$ & $\begin{array}{l}\text { Academic Line Manager, Subject/Programme Panel } \\
\text { Chair, Programme Leader, Year Leader, Personal } \\
\text { Tutor, Module Coordinator, Module Delivery } \\
\text { (Lectures), Module Delivery (Tutorials/Labs), Project } \\
\text { Supervisor }\end{array}$ \\
\hline \multicolumn{2}{|l|}{$\begin{array}{l}\text { How long have you been teaching? } \\
\text { (educators) }\end{array}$} \\
\hline Which of the following are you? (students) & $\begin{array}{l}\text { Full time undergraduate, Full time postgraduate, Part } \\
\text { time undergraduate, Part time postgraduate, Other }\end{array}$ \\
\hline $\begin{array}{l}\text { How is your course currently being } \\
\text { taught?(select all that apply)(students) }\end{array}$ & $\begin{array}{l}\text { Traditional (lectures, tutorials and labs), Distance } \\
\text { learning, mLearning (mobile learning), Other Another } \\
\text { method or a combination of the above methods } \\
\text { (Please specify), Other (please specify) }\end{array}$ \\
\hline $\begin{array}{l}\text { Please select your year of study? Click } 1 \text { for } \\
\text { first year and } 2 \text { for second year etc (students) }\end{array}$ & Year 1, Year 2, Year 3, Year 4, Year 5, Year 6 \\
\hline \multicolumn{2}{|c|}{ Feedback methods } \\
\hline $\begin{array}{l}\text { When do you give feedback to students? } \\
\text { (Educators) }\end{array}$ & $\begin{array}{l}\text { Weekly, Fortnightly, Monthly, Whenever it is } \\
\text { required, Only after assignment, Other (please } \\
\text { specify) }\end{array}$ \\
\hline \multicolumn{2}{|l|}{$\begin{array}{l}\text { What could be the reason(s) for not giving } \\
\text { feedback on student's work? (educators) }\end{array}$} \\
\hline $\begin{array}{l}\text { Generally how often do your } \\
\text { lecturers/tutors/supervisors give you feedback } \\
\text { on your work? (students) }\end{array}$ & $\begin{array}{l}\text { Daily, Weekly, Fortnightly, Monthly, Whenever it is } \\
\text { required, Only after assignment, Never, Never, please } \\
\text { tell us why }\end{array}$ \\
\hline $\begin{array}{l}\text { Are you given the opportunity to choose the } \\
\text { feedback method (s) you prefer? (students) }\end{array}$ & Yes, No, If No please tell us why \\
\hline $\begin{array}{l}\text { Are students given the opportunity to choose } \\
\text { the feedback methods they prefer? (educators) }\end{array}$ & Yes, No, If No please tell us why \\
\hline $\begin{array}{l}\text { Have you ever been unhappy with the } \\
\text { feedback you receive from your tutors } \\
\text { /lecturers / supervisors? (students) }\end{array}$ & Yes, No, If Yes, please tell us why \\
\hline
\end{tabular}




\begin{tabular}{|c|c|}
\hline $\begin{array}{l}\text { When do you get feedforward? (Feedforward } \\
\text { comments are suggestions that would be } \\
\text { helpful in future course works or } \\
\text { assignments.) (students) }\end{array}$ & $\begin{array}{l}\text { After the class, Weekly, Fortnightly, Monthly, Only if } \\
\text { I request, After the module, Never }\end{array}$ \\
\hline $\begin{array}{l}\text { Do you give feedforward? (Feedforward } \\
\text { comments are suggestions that would be } \\
\text { helpful in future course works or } \\
\text { assignments.) (educators) }\end{array}$ & $\begin{array}{l}\text { Yes, Sometimes, If requested, No, If No, please tell } \\
\text { us why }\end{array}$ \\
\hline $\begin{array}{l}\text { When do you give feedback to your } \\
\text { lecturers/tutors on their teaching? (students) }\end{array}$ & $\begin{array}{l}\text { After the class, Weekly, Fortnightly, Monthly, } \\
\text { Whenever it is required, After the module, Never, } \\
\text { Never, please tell us why }\end{array}$ \\
\hline $\begin{array}{l}\text { When do you get feedback from students on } \\
\text { the subject (s) you teach? (educators) }\end{array}$ & $\begin{array}{l}\text { End of class, End of the module, End of course, Other } \\
\text { (please specify) }\end{array}$ \\
\hline $\begin{array}{l}\text { Do you use comparison in feedback? If yes } \\
\text { which one(s)? (educators) }\end{array}$ & $\begin{array}{l}\text { Criterion referencing (feedback against clear criteria), } \\
\text { Self-referenced feedback (helps describing the } \\
\text { processes or methods students use), Norm referenced } \\
\text { feedback (compares a student's performance to the } \\
\text { performance of other students), None, Other (please } \\
\text { specify) }\end{array}$ \\
\hline $\begin{array}{l}\text { What content (s) does the feedback given to } \\
\text { (you) your students focus on? Please, choose } \\
\text { more than one if applicable (students } \& \\
\text { educators) }\end{array}$ & $\begin{array}{l}\text { Information about the depth or quality of the work, } \\
\text { Information about neatness or format, } \\
\text { How the task was approached, } \\
\text { Whether the topic was covered, } \\
\text { How well the topic was covered, } \\
\text { Whether what they did match up with what they were } \\
\text { asked to do, } \\
\text { Including alternative useful strategies to do the task, } \\
\text { Why the wrong answer is wrong, } \\
\text { Why the right answer is correct, } \\
\text { Identifying the strengths and weaknesses in the work, } \\
\text { Making suggestions to improve to task }\end{array}$ \\
\hline $\begin{array}{l}\text { What issue (s) do you think affect the } \\
\text { provision of effective feedback? (educators) }\end{array}$ & \\
\hline $\begin{array}{l}\text { From the list below, how is feedback given to } \\
\text { you and which method (s) of feedback would } \\
\text { you prefer if you had a choice? (students) } \\
\text { Email, Face-to-Face, Written, Blackboard } \\
\text { (notes alongside grades), Podcast (on } \\
\text { Blackboard or email), SMS, Videocast, Blog, } \\
\text { Wikis, Other (please specify) }\end{array}$ & $\begin{array}{l}\text { Definitely wouldn't, Probably wouldn't, Already } \\
\text { getting, Probably would, Definitely would }\end{array}$ \\
\hline $\begin{array}{l}\text { From the list below, which method (s) of } \\
\text { feedback do you use or would you use if } \\
\text { requested by your students? (educators) } \\
\text { Email, Face-to-Face, Written, Blackboard } \\
\text { (notes alongside grades), Podcast (on } \\
\text { Blackboard or email), SMS, Videocast, Blog, } \\
\text { Wikis, Other (please specify) }\end{array}$ & $\begin{array}{l}\text { Definitely wouldn't, Probably wouldn't, Already } \\
\text { using Probably would, Definitely would }\end{array}$ \\
\hline \multicolumn{2}{|c|}{ On Social Media Experience } \\
\hline $\begin{array}{l}\text { Which of the following Web 2.0/social } \\
\text { networking applications do you use at UWS } \\
\text { for teaching/learning/research purposes? }\end{array}$ & $\begin{array}{l}\text { Facebook, Twitter, Wikis, Blogs, Bebo, Youtube, } \\
\text { Flickr, MySpace, GoogleMaps, Mobile Instant } \\
\text { Messaging (Mobile IM), RSS (Really Simple }\end{array}$ \\
\hline
\end{tabular}


(Select more than one if applicable) (students \& educators)

Syndication), Skype, Poll Everywhere, LinkedIn, Screencast-o-matic, Camtasia Relay, Yammer

If you don't use any Web 2.0/social

networking application, please tell us why

How often (approximately) do you use any of the Web 2.0/Social networking applications

for the following teaching/learning activities? (students \& educators)

Text messaging, Interaction with students (chat), File sharing (pictures, video, and documents), Downloading learning material, Discussion with peers, Test/quizzes,

Discussion with peers, Game-based learning, Other teaching/learning activities

If you answered 'Never' to all the items of the above question, please state which of the above or other teaching/learning activities you would consider using Web 2.0 Applications for? (students \& educators)

The university may wish to contact students via Web 2.0/Social networking applications available on Blackboard for learning purposes (e.g.: Feedback). In your opinion how acceptable would that be? (students \& educators)

How useful would it be for you to communicate with your students (with your lecturer / tutor / supervisor) via Web 2.0/Social networking applications available on Blackboard for learning purposes (e.g.: Feedback)? (students \& educators)

Several times per, day, daily weekly, Fortnightly, Monthly Never
Very useful, Useful, Neutral, Unuseful, Very unuseful 